\title{
Changes in biological soil quality indicators under saline soil condition after amelioration with alfalfa (Medicago sativa $\mathrm{L}$.) cultivation in meadow Solonchak
}

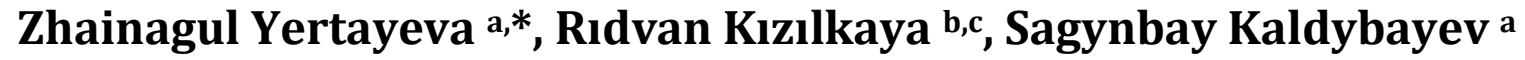 \\ Nurzikhan Seitkali a, Nurgul Abdraimova a, Aigul Zhamangarayeva a \\ a Kazakh National Agrarian University, Almaty, Kazakhstan
}

b Ondokuz Mayıs University, Faculty ofAgriculture, Department of Soil Science and Plant Nutrition, Samsun, Turkey

c Agrobigen Research \& Development Trade Ltd.Co, Samsun Technopark, Samsun, Turkey

\section{Article Info}

Received : 16.06 .2018

Accepted : 10.04 .2019

\begin{abstract}
Land use and amelioration practices are considered as main drivers in change of biological soil quality indicators in meadow Solonchaks. To gain insight into the impact of amelioration with alfalfa (Medicago sativa L.) cultivation on the underlying soil microbiological and biochemical properties, the objective of this study was to determine the effect of alfalfa (Medicago sativa L.) cultivation on biological soil quality indicators such as microorganisms counts, microbial biomass, basal soil respiration and enzyme activities (dehydrogenase, catalase, $\beta$-glucosidase, protease, urease, alkaline phosphatase and arylsulphatase) in meadow Solonchak. Post-amelioration with alfalfa cultivation influenced the soil microbiological and biochemical properties and increased soil organic matter content and improved biological soil quality indicators. The results of this study may contribute to future researches for soil microbial communities in different type of amelioration practices in soil quality and sustainable productivity meadow Solonchaks.

Keywords: Amelioration, microorganisms, saline soil, soil quality.
\end{abstract}

(C) 2019 Federation of Eurasian Soil Science Societies. All rights reserved

\section{Introduction}

Soil salinity is one of the most serious abiotic factors restricting productivity of field, plant diversity and plant growth in arid and semi-arid regions, where soil salt content is high and precipitation is insufficient (Kazemi and Eskandari, 2011) Worldwide, about 30 million ha are severely affected by salinity and an additional almost 80 million ha are estimated to be affected to some extent (Umali, 1993). The area of saline soils in Kazakhstan, including Solonetz, alkaline soils, and complexes of Solonetz with other soils, is 111.55 million ha, or $41 \%$ of the national territory (FAO, 2015). Saline soils are present everywhere in the country except in mountainous areas. They are common in the steppe zone, where they cover about $30 \%$ of the area. In dry steppe, semi-desert and desert zones these soils occupy up to $50 \%$ of the area. Salt-affected soils are represented mainly by Solonetz and alkaline soils. Solonchaks cover only 1-3\% of the area of salt-affected soils in the steppe zone, and $7-13 \%$ of the area of salt-affected soils in the semi-desert and desert zones (FAO, 2015).

The amelioration of problem soils is a very important goal throughout the world, especially with saline or saline-sodic soils (Mady, 2011). Sodic and saline-sodic soils possess poor physical properties and fertility problems that adversely affect the growth and yield of most crops (Sumner 1993; Grattan and Grieve, 1999). Saline-sodic soils reclamation is one of the main problems for humans in the future. The reclamation of

\footnotetext{
${ }^{*}$ Corresponding author.

Kazakh National Agrarian University, Almaty, Kazakhstan

Tel.: +7 7025050404

e-ISSN: 2147-4249
} DOI: $10.18393 /$ ejss.552563 
saline soils uses many different methods such as physical amelioration (deep ploughing, subsoiling, sanding, profile inversion), chemical amelioration (amending of soil with various reagents: gypsum, calcium chloride, limestone, sulphuric acid, sulphur, iron sulphate) and biological amelioration (Oad et al., 2002). The biological amelioration methods using living (sowing new forms of leguminous plants) or dead organic matter (crops, stems, straw, green manure, barnyard manure, compost, sewage sludge) (Matsumoto et al., 1994) have two principal beneficial effects on the saline and alkaline soils reclamation: the improvement of the soil structure and permeability, thus enhancing salt leaching, reducing surface evaporation, and inhibiting salt accumulation in the surface layers; and the release of carbon dioxide during respiration and decomposition. For saline or sodic soils, the addition of organic matter can accelerate the leaching of $\mathrm{Na}$, decrease the exchangeable Na percentage and electrical conductivity, and increase water infiltration, waterholding capacity, and aggregate stability (Lax et al., 1994; Qadir et al., 2001). Thus, the increase in the yield and quality of agricultural cultures, particularly in arid areas and on saline soils, can be achieved through the high-culture farming by scientifically sound ecologically safe use of new types of bio-fertilizer and biologics, sowing new forms of leguminous plants (especially leguminous vegetable), bio-amelioration with halophytes that have a positive effect on the biological soil quality indicators such as microbiological and enzymatic activities, soil respiration and the processes of humus-forming in soil, and, finally, soil fertility and productive capacity (Mady, 2011).

Soil quality has been defined as "the capacity of a soil to function within ecosystem and land-use boundaries, to sustain biological productivity, maintain environmental quality and promote plant and animal health" (Karlen et al., 1997) and can be assessed using a wide variety of biological, physical and chemical indicators (Doran and Parkin, 1994). Biological indicators typically include microbial biomass carbon (Jordan et al., 1995; Karlen et al., 1997) and microbial enzyme activities (Bandick and Dick, 1999; Eivazi et al., 2003). Microbial enzyme activities reflect metabolic factors and may serve as early indicators of soil quality improvement or degradation in agroecosystems (Dick, 1994). The purposes of the present work were to compare biological soil quality indicators such as microbial biomass carbon, enzyme activities and basal soil respiration between saline soil conditions and ameliorated soil with alfalfa (Medicago sativa L.) cultivation in meadow Solonchak of South Kazakhstan.

\section{Material and Methods}

\section{Study site description}

Experimental studies were carried out at the Teskensu (Kaz.Teskensu) village in the Enbekshikazakh district $\left(43^{\circ} 32^{\prime} \mathrm{N}, 77^{\circ} 51^{\prime} \mathrm{E}\right)$ of the Almaty region of Kazakhstan (Figure 1). The study area is situated between 601 $\mathrm{m}$ elevation from sea level.

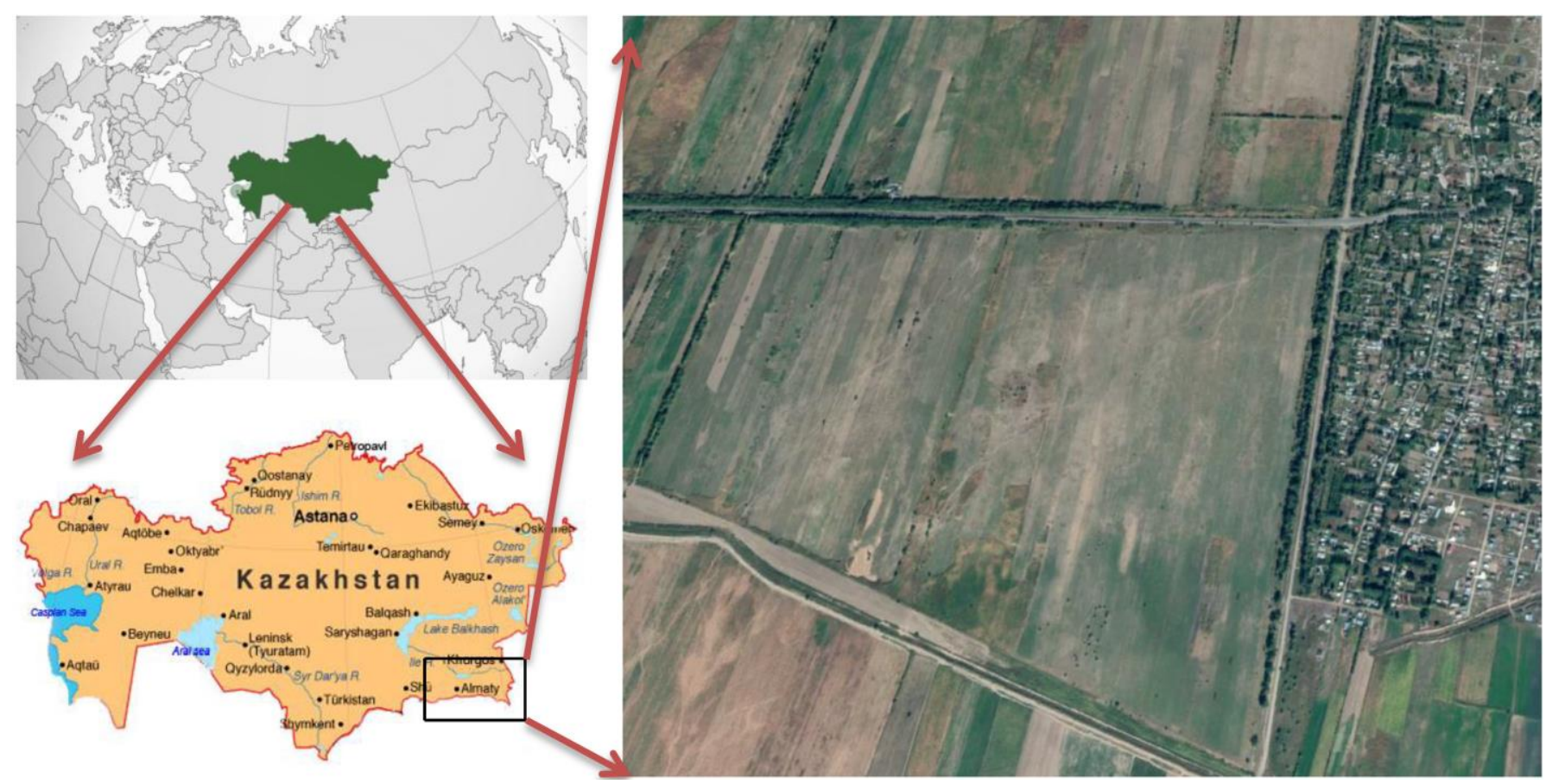

Figure 1. Location map of the study area 
The climate type of study area is "Continental Climate" which can be described as low humidity, plenty of sunlight, a short but rather cold winter. The average annual air temperature is $12.3^{\circ} \mathrm{C}$, total rainfall is 275.7 $\mathrm{mm}$. The average long-term sum of precipitation for a period with temperature above $10^{\circ} \mathrm{C}$ is $198-245 \mathrm{~mm}$.

\section{The field experiment}

Between 1985 and 1989, the field experiment established by S. Kaldybayev to ameliorate with alfalfa (Medicago sativa L.) cultivation soils in some parts of meadow Solonchaks (Beketova et al., 2017; Yerteyeva et al., 2018). From 1989 until 2017, alternating leguminous plants (especially leguminous vegetable and alfaalfa) were grown integrated production without other amelioration methods in bio-ameliorated meadow Solonchaks. Other parts in meadow Solonchak is virgin land.

\section{Soil sampling}

Soil samples were taken on 27 May 2017 as a bulked sample from ameliorated soils and virgin lands from 0 to $20 \mathrm{~cm}$ soil depth (plough layer). The soil samples had $43.56 \%$ clay, $40.29 \%$ silt and $16.15 \%$ sand. Soil samples were dried under atmospheric condition and passed through a $2 \mathrm{~mm}$ sieve to prepare for laboratory analysis. In soil samples, $\mathrm{CaCO}_{3}$ content by Scheibler calsimeter, $\mathrm{pH}$ in 1:1 (w/v) soil: $\mathrm{dH}_{2} \mathrm{O}$ suspension by $\mathrm{pH}-$ meter, electrical conductivity (EC) in the same soil suspension by EC-meter, exchangeable cations $\left(\mathrm{Na}^{+}, \mathrm{K}^{+}\right.$, $\mathrm{Ca}^{2+}$ and $\mathrm{Mg}^{2+}$ ) were measured using a $1 \mathrm{~N} \mathrm{NH}_{4} \mathrm{OAc}(\mathrm{pH} 7)$ extraction, water soluble exchangeable cations $\mathrm{pH}$ in $1: 1(\mathrm{w} / \mathrm{v})$ soil: $\mathrm{dH}_{2} \mathrm{O}$. All soil samples were sieved through a $150 \mu \mathrm{m}$ mesh before determining the total organic carbon content ( $\mathrm{C}_{\mathrm{org}}$ ) by the wet oxidation method (Walkley-Black) with $\mathrm{K}_{2} \mathrm{Cr}_{2} \mathrm{O}_{7}$ (Rowell, 1996).

\section{Measurement of biological soil quality indicators}

\section{Microbiological indicators}

Microbiological counts were expressed as a number of colony forming units (CFUs) per g of dry soil. The total number of bacteria was determined by the dilution method on agarized soil extract. The total number of fungi was determined on the Martin's medium (Martin, 2003). Ten grams of each soil sample were added to $95 \mathrm{~mL}$ of $0.1 \%(\mathrm{w} / \mathrm{v}$ ) solution of sodium pyrophosphate. After homogenization for $30 \mathrm{~min}$, this solution was decimally diluted (10-1 to 10-7) and aliquots of the resulting solutions plated on appropriate culture media. After incubation at 25 or $30^{\circ} \mathrm{C}$, for up to 10 days, the colony forming units (CFU) were counted. Data were expressed as colony forming units (CFU) g-1 dry soil.

Microbial biomass carbon $\left(\mathrm{C}_{\text {mic }}\right)$ was determined by the substrate-induced respiration method of by Anderson and Domsch (1978). A moist sample equivalent to $10 \mathrm{~g}$ oven-dry soil was amended with a powder mixture containing $40 \mathrm{mg}$ glucose. The $\mathrm{CO}_{2}$ production rate was measured hourly using the method described by Anderson (1982). The pattern of respiratory response was recorded for $4 \mathrm{~h}$. Microbial biomass carbon $\left(\mathrm{C}_{\mathrm{mic}}\right)$ was calculated from the maximum initial respiratory response in terms of $\mathrm{mg} \mathrm{C} \mathrm{g}^{-1}$ soil as 40.04 $\mathrm{mg} \mathrm{CO} \mathrm{g}^{-1}+3,75$. Data were expressed as $\mathrm{mg} \mathrm{C}^{-1}$ dry soil.

Basal soil respiration (BSR) at field capacity $\left(\mathrm{CO}_{2}\right.$ production at $22^{\circ} \mathrm{C}$ without addition of glucose) was measured, as reported by Anderson (1982); by alkali $\left(\mathrm{Ba}(\mathrm{OH})_{2} \cdot 8 \mathrm{H}_{2} \mathrm{O}+\mathrm{BaCl}_{2}\right.$ ) absorption of the $\mathrm{CO}_{2}$ produced during the $24 \mathrm{~h}$ incubation period, followed by titration of the residual $\mathrm{OH}^{-}$with standardized hydrochloric acid, after adding three drops of phenolphthalein as an indicator. Data were expressed as $\mu \mathrm{g}$ $\mathrm{CO}_{2}-\mathrm{C} \mathrm{g}^{-1}$ dry soil.

\section{Enzyme activities}

Dehydrogenase activity (DHA) was determined according to Pepper et al. (1995). To $6 \mathrm{~g}$ of sample $30 \mathrm{mg}$ glucose, $1 \mathrm{ml}$ of $3 \%$ TTC (2,3,5-triphenyltetrazoliumchlorid) solution and $2.5 \mathrm{ml}$ pure water were added and the samples were incubated for $24 \mathrm{~h}$ at $37^{\circ} \mathrm{C}$. The formation of TPF $(1,3,5$ triphenylformazan) was determined spectrophotometrically at $485 \mathrm{~nm}$ and results were expressed as $\mu \mathrm{g} \mathrm{TPF} \mathrm{g-1}$ dry sample. Catalase activity (CA) was measured by the method of Beck (1971). Ten ml of phosphate buffer (pH, 7) and $5 \mathrm{ml}$ of a $3 \% \mathrm{H}_{2} \mathrm{O}_{2}$ substrate solution were added to $5 \mathrm{~g}$ of sample. The volume $(\mathrm{ml})$ of $\mathrm{O}_{2}$ released within 3 minutes at $20^{\circ} \mathrm{C}$ was determined. Three replicates of each sample were tested and controls were tested in the same way, but with the addition of $2 \mathrm{ml}$ of $6.5 \%\left(\mathrm{w} / \mathrm{v}\right.$ ) $\mathrm{NaN}_{3}$. Results were expressed as $\mathrm{ml} \mathrm{O}_{2} \mathrm{~g}^{-1}$ dry soil. $\beta$ glucosidase activity (GA) was measured according to Eivazi and Tabatabai (1988). $0.25 \mathrm{ml}$ toluene, $4 \mathrm{ml}$ TRIS (hydroximethyl) aminomethane buffer $(\mathrm{pH}, 12)$ and $1 \mathrm{ml}$ of $0.05 \mathrm{M} p$-nitrophenyl $\beta$-D-glucopyranoside solution were added to the $1 \mathrm{~g}$ sample and the samples were incubated for $1 \mathrm{~h}$ at $37^{\circ} \mathrm{C}$. The formation of $p$ nitrophenol was determined spectrophotometrically $410 \mathrm{~nm}$ and results were expressed as $\mu \mathrm{g} p$ nitrophenol g-1 dry soil. Protease activity was measured according to Ladd and Butler (1972). Using casein as a substrate, soil samples were incubated for $2 \mathrm{~h}$ at $50^{\circ} \mathrm{C}$ at $\mathrm{pH}$ 8.1. Amino acids released during the 
incubation period were extracted, and the remaining substrate was precipitated after the addition of trichloroacetic acid. Aromatic amino acids react with Folin-Ciocalteu phenol reagent in an alkaline solution to form a blue complex, which was determined spectrophotometrically and results were expressed as $\mu \mathrm{g}$ Tyrosn $\mathrm{g}^{-1}$ dry soil.

Urease activity (UA) was measured by the method of Hoffmann and Teicher (1961). $0.25 \mathrm{ml}$ toluene, $0.75 \mathrm{ml}$ citrate buffer $(\mathrm{pH}, 6.7)$ and $1 \mathrm{ml}$ of $10 \%$ urea substrate solution were added to the $1 \mathrm{~g}$ sample and the samples were incubated for $3 \mathrm{~h}$ at $37^{\circ} \mathrm{C}$. The formation of ammonium was determined spectrophotometrically at $578 \mathrm{~nm}$ and results were expressed as $\mu \mathrm{g} \mathrm{N} \mathrm{g-1}$ dry soil. Alkaline phosphatase activity (APA) was determined according to Tabatabai and Bremner (1969). 0,25 ml toluene, $4 \mathrm{ml}$ phosphate buffer $(\mathrm{pH}, 8.0)$ and $1 \mathrm{ml}$ of $0,115 \mathrm{M} p$-nitrophenyl phosphate (disodium salt hexahydrate) solution were added to the $1 \mathrm{~g}$ sample and the samples were incubated for $1 \mathrm{~h}$ at $37^{\circ} \mathrm{C}$. The formation of $p$-nitrophenol was determined spectrophotometrically at $410 \mathrm{~nm}$ and results were expressed as $\mu \mathrm{g} p$-nitrophenol g-1 dry soil. Arylsulphatase activity (ASA) was measured according to Tabatabai and Bremner (1970). $0.25 \mathrm{ml}$ toluene, 4 $\mathrm{ml}$ acetate buffer $(\mathrm{pH}, 5.5)$ and $1 \mathrm{ml}$ of $0.115 \mathrm{M} p$-nitrophenyl sulphate (potassium salt) solution were added to the $1 \mathrm{~g}$ sample and the samples were incubated for $1 \mathrm{~h}$ at $37^{\circ} \mathrm{C}$. The formation of $p$-nitrophenol was determined spectrophotometrically $410 \mathrm{~nm}$ and results were expressed as $\mu \mathrm{g} p$-nitrophenol g-1 $\mathrm{dry}$ soil. All determinations of biological soil quality indicators were performed in triplicate, and all values reported are averages of the three determinations expressed on an oven-dried soil basis $\left(105^{\circ} \mathrm{C}\right.$ ).

\section{Results and Discussion}

Some chemical properties of ameliorated and virgin land soils are given in Table 1. As shown in Table 1; soil $\mathrm{pH}$, $\mathrm{EC}, \mathrm{CaCO}_{3}$, water soluble cations and exchangeable cations were higher in virgin land than in the ameliorated land.

Table 1. Some soil chemical properties of ameliorated and virgin land of meadow Solonchack.

\begin{tabular}{lcc}
\hline Soil chemical properties & Ameliorated land & Virgin land \\
\hline $\mathrm{pH}$ & 8.35 & 9.02 \\
$\mathrm{EC}, \mathrm{dSm}^{-1}$ & 0.76 & 3.32 \\
Organic matter, \% & 2.60 & 0.56 \\
$\mathrm{CaCO}_{3}, \%$ & 12.19 & 18.22 \\
Water soluble cations, $\mathrm{dSm}^{-1}$ & & \\
$\quad \mathrm{Na}^{+}$ & 1.09 & 5.89 \\
$\mathrm{~K}^{+}$ & 0.39 & 0.42 \\
$\mathrm{Ca}^{2+}$ & 1.02 & 18.59 \\
$\mathrm{Mg}^{2+}$ & 0.76 & 6.59 \\
$\quad$ & \\
$\quad \mathrm{Na}^{+}$ & 1.05 & 3.79 \\
$\mathrm{~K}^{+}$ & 0.70 & 0.72 \\
$\mathrm{Ca}^{2+}$ & 15.24 & 58.11 \\
$\mathrm{Mg}^{2+}$ & 4.19 & 5.17 \\
\hline
\end{tabular}

\section{Biological soil quality indicators}

In this study two categories of biological soil quality indicators were used: microbiological indicators and enzyme activities. Biological soil quality indicators of ameliorated and virgin lands are presented in Table 2 .

Table 2. Biological soil quality indicators in ameliorated and virgin land of meadow Solonchack.

\begin{tabular}{|c|c|c|}
\hline Biological soil quality indicators & Ameliorated land & Virgin land \\
\hline \multicolumn{3}{|l|}{ Microbiological indicators } \\
\hline Bacteria count, $\mathrm{CFU} \mathrm{g}^{-1}$ dry soil & $5 \times 10^{8}$ & $2 \times 10^{6}$ \\
\hline Fungi count, $\mathrm{CFU} \mathrm{g}^{-1}$ dry soil & $3 \times 10^{3}$ & $5 \times 10^{2}$ \\
\hline $\mathrm{C}_{\text {mic }}, \mathrm{mg} \mathrm{C} \mathrm{g}^{-1}$ dry soil & 326,36 & 162,72 \\
\hline BSR, $\mu \mathrm{g} \mathrm{CO}_{2}-\mathrm{C} \mathrm{g}^{-1}$ dry soil & 75,41 & 36,37 \\
\hline \multicolumn{3}{|l|}{ Enzyme activities } \\
\hline DHA, $\mu$ g TPF g-1 dry soil & 58,15 & 25,11 \\
\hline $\mathrm{CA}, \mathrm{ml} \mathrm{O}_{2} \mathrm{~g}^{-1}$ dry soil & 5,69 & 5,11 \\
\hline $\mathrm{GA}, \mu \mathrm{g} p$-nitrophenol $\mathrm{g}^{-1} \mathrm{dry}$ soil & 12,69 & 3,58 \\
\hline $\mathrm{UA}, \mu \mathrm{g} \mathrm{N} \mathrm{g}{ }^{-1}$ dry soil & 8,68 & 4,29 \\
\hline PA, $\mu$ g Tyrosn $\mathrm{g}^{-1}$ dry soil & 89,54 & 36,72 \\
\hline APA, $\mu \mathrm{g} p$-nitrophenol $\mathrm{g}^{-1}$ dry soil & 27,36 & 5,96 \\
\hline ASA, $\mu \mathrm{g} p$-nitrophenol $\mathrm{g}^{-1}$ dry soil & 19,56 & 8,75 \\
\hline
\end{tabular}




\section{Microbiological indicators}

Soil microorganisms play an important role as regulators of major biogeochemical cycles and can significantly affect the ecosystem functioning (Tiedje et al., 1999), being involved in organic matter dynamics, nutrient cycling and decomposition processes (Nannipieri et al., 2003). Because of these reasons, microbial populations are important in soil fertility and quality. The anthropogenic activities affect the diversity of natural habitats modifying the number of species occurring in the environment at the landscape scale. In this study, it was determined that melioration practices strongly influenced bacteria and fungi populations in soils, and the virgin land soil had the lower bacteria and fungi population than ameliorated land soil (Table 2). Therefore, microbial population and their activities in response to amelioration practices is a fundamental indicator for sustainability of ecosystem processes.

We accept that $C_{m i c}$ gives an idea of the potential microbial activity of a soil (Nannipieri et al., 1990). The incorporation of organic matter by amelioration with alfalfa (Medicago sativa L.) cultivation in soil raised the $\mathrm{C}_{\text {mic }}$ level significantly, which reflects the increased number of microorganisms (Table 2). The general increase in $\mathrm{C}_{\text {mic }}$ noted can be attributed to the incorporation of easily biodegradable organic materials (Perucci, 1992). In addition, favorable conditions in ameliorated land and the higher content of organic matter (Table 1), which acts as energy source for the microorganisms, thus contributing to an increase in their activity and biomass. Anderson (1982) defined BSR as a useful parameter in measuring a soil's biological activity. High contents of organic matter and microbial populations significantly raised the BSR in ameliorated land (Table 2). Hence, favorable conditions result in increase in the size of the microbial biomass and the efficiency of $\mathrm{C}$ substrates degradation, conducting to an increase in respiration rate per unit of microbial biomass.

\section{Enzyme activities}

Enzyme activity is essential in both mineralization and transformation of organic $\mathrm{C}$ and plant nutrients. Hence, enzyme measurements have been used to determine effects of agricultural and/or amelioration practices on soil microorganisms as Biological soil quality indicators. As presence of dehydrogenases, which are intracellular to the microbial biomass, is common throughout microbial species and they are rapidly degraded following the cell death, the measurement of microbial DHA in soils has been used extensively (Bolton et al., 1985; Rossel and Tarradellas, 1991; Obbard, 2001). Therefore, usage of DHA as an index of microbial activity has been suggested (Benefield et al., 1977; Nannipieri et al., 1990; Tabatabai, 1994; Masciandaro et al., 2000). The CA is based on the rates of oxygen release from the added hydrogen peroxide, and may be related to the metabolic activity of aerobic organisms (Kizllkaya et al., 2004). The virgin land soil had the lower DHA and CA enzyme activity than ameliorated land soil (Table 2).

The GA, PA, UA, APA and ASA are good markers of biological fertility since they are involved in microbial cycling of $\mathrm{C}, \mathrm{N}, \mathrm{P}$ and $\mathrm{S}$. The GA catalyzes the hydrolysis of $\beta$-D-glucopyranoside and is one of the three or more enzymes involved in the saccharification of cellulose (Bandick and Dick, 1999; Turner et al., 2002). The PA hydrolyze proteins to polypeptides, oligopeptides, and amino acids. As most $\mathrm{N}$ compounds in mineral soils are organically bound, these transformations are necessary to release $\mathrm{N}$ for plant uptake (Okur et al., 2009). The UA is involved in the hydrolysis of urea to carbondioxide and ammonia, which can be assimilated by microbes and plants. It acts on carbon-nitrogen $(\mathrm{C}-\mathrm{N})$ bonds other than the peptide linkage (Bremner and Mulvaney, 1978). The APA hydrolyzes compounds of organic phosphorus and transforms them into basically phosphate ions of inorganic phosphorus, which are assimilate by plants (Amador et al., 1997). The ASA is the enzyme involved in the hydrolysis of arylsulphate esters by fission of the oxygen-sulphur (O-S) bond. This enzyme is believed to be involved in the mineralization of ester sulphate in soils (Tabatabai, 1994). In this study, activity of all the studied extracellular enzymes was significantly higher in the ameliorated land soil than in the virgin land soil samples (Table 2). Higher extracellular enzyme activity in ameliorated land soil is related higher content of organic matter content (Table 1).

Several studies (Kızılkaya and Bayraklı, 2005; Aşkın and Kızılkaya, 2006; Kızılkaya and Hepşen, 2007) showed that the soils including high organic matter content have higher enzyme activities such as; intracellular (DHA and CA) and extracelluar-hydrolytic enzymes (GA, PA, UA, APA and ASA) than the soils including low organic matter content. During the biological amelioration period with alfalfa, post harvesting material might have decomposed, resulting in higher enzymes in ameliorated land soil. In addition, increased content of organic carbon and nutrients may increase enzymes in ameliorated land soil. Some research were reported that increasing organic matter and available nutrients were increased to enzyme activity, (Leirós, et al., 2000; Kızllkaya, 2005). It is possible that the increasing organic material had stimulated microbial production of enzymes (GA, PA, UA, APA and ASA) in soil, or supported more enzymes accessible to substrate. 


\section{Conclusion}

Overall, data obtained in this work revealed an important effect of amelioration practices on biological soil quality indicators. Soil microbial communities and their enzymatic activities exhibited compositional shifts that tracked with changes in land amelioration. This study, combining the microbiological and biochemical data furnishes a good methodological approach to describe the influence of bio-amelioration with alfalfa (Medicago sativa L.) cultivation on biological soil quality indicators. In fact, the results demonstrate that in the same pedological conditions, amelioration activities that influence the microbiological properties and their activities in soils, showed a more stable and higher microbiological and biochemical soil composition as well as intra and extracellular enzyme activities compare with virgin land soil. Further researches are required to determine whether the observed shifts in microbial community composition produce parallel changes in the functional attributes of these communities across soil types under different type of amelioration practices. The use of culture-independent approaches, like metagenome sequencing, will make it possible to identify the specific drivers of land amelioration and land use dynamics exhibited by soil microbial communities and to give a complete picture of the microbial communities in a typical meadow Solonchaks.

\section{References}

Amador, J.A., Glucksman, A.M., Lyons, J.B., Görres, J.H., 1997. Spatial distribution of soil phosphatase activity within a riparian forest. Soil Science 162(11): 808-825.

Anderson, J.P.E., 1982. Soil respiration. In. Methods of soil analysis, Part 2- Chemical and Microbiological Properties, Page, A.L., Keeney, D. R., Baker, D.E., Miller, R.H., Ellis, R. Jr., Rhoades, J.D. (Eds.). ASA-SSSA, Madison, Wisconsin, USA. pp. 831-871.

Anderson, J.P.E., Domsch, K.H., 1978. A physiological method for the quantative measurement of microbial biomass in soils. Soil Biology and Biochemistry 10(3): 215 - 221.

Aşkın, T., Kızılkaya, R., 2006. Assessing spatial variability of soil enzyme activities in pasture topsoils using geostatistics. European Journal of Soil Biology 42(4): 230-237.

Bandick, A.K., Dick, R.P., 1999. Field management effects on soil enzyme activities. Soil Biology and Biochemistry 31(11): 1471-1479.

Beck, T.H., 1971. Die Messung derkKatalasen aktivität Von Böden. Zeitschrift für Pflanzenernährung und Bodenkunde 130(1): 68-81.

Beketova, A.K., Kaldybaev, S., Yertayeva, Z., 2017. Changes in the Composition and Properties of Meadow Solonchaks of the Ili Alatau Foothill Plain in the Republic of Kazakhstan during a Long Postmeliorative Period. OnLine Journal of Biological Sciences 17(4): 290.298.

Benefield, C.B., Howard P.J.A., Howard, D.M., 1977. The estimation of dehydrogenase activity in soil. Soil Biology and Biochemistry 9(1): 67-70.

Bolton, Jr.,H., Elliott, L.F., Papendick, R.I., Bezdicek, D.F., 1985. Soil microbial biomass and selected soil enzyme activities: effect of fertilization and cropping practices. Soil Biology and Biochemistry 17(3): 297-302.

Bremner, J.M., Mulvaney, R.L., 1978. Urease activity in soils. In: Soil enzymes, Burns, R.G. (Ed.). Academic Press, New York, USA.pp.149-196.

Dick, R.P., 1994. Soil enzyme activity as an indicator of soil quality. In: Defining soil quality for a sustainable environment. Doran, J.W., Coleman, D.C., Stewart, B.A., Bezdicek, D.F. (Eds.). SSSA Special Publication No. 35. Madison, Wisconsin, USA. pp. 107-124.

Doran, J.W., Parkin, T.B., 1994. Defining and assessing soil quality. In: Defining soil quality for a sustainable environment. Doran, J.W., Coleman, D.C., Stewart, B.A., Bezdicek, D.F. (Eds.). SSSA Special Publication No. 35. Madison, Wisconsin, USA. pp. 3-21.

Eivazi, F., Bayan, M., Schmidt, K., 2003. Select soil enzyme activities in the historic Sanborn Field as affected by longterm cropping systems. Communications in Soil Science and Plant Analysis 34(15/16): 2259-2275.

Eivazi, F., Tabatabai, M.A., 1988. Glucosidases and galactosidases in soils. Soil Biology and Biochemistry 20(5): 601-606.

FAO, 2015. Status of the World's Soil Resources (SWSR) - Main Report. Chapter II Regional assessment of soil changes in Europe and Eurasia. Food and Agriculture Organization of the United Nations and Intergovernmental Technical Panel on Soils, Rome, Italy. 363p. http://www.fao.org/3/a-bc600e.pdf

Grattan, S.R., Grieve, C.M., 1999. Salinity-mineral nutrient relations in horticultural crops. Scientia Horticulturae 78(14): 127-157.

Hoffmann, G.G., Teicher, K., 1961. Ein Kolorimetrisches Verfahren zur Bestimmung der Urease Aktivitat in Böden. Zeitschrift für Pflanzenernährung und Bodenkunde 95(1): 55-63.

Jordan, D., Kremer, R.J., Bergfield, W.A., Kim, K.Y., Cacnio, V.N., 1995. Evaluation of microbial methods as potential indicators of soil quality in historical agricultural fields. Biology and Fertility of Soils 19(4):297-302.

Karlen, D.L., Mausbach, M.J., Doran, J.W., Cline, R.G., Harris, R.F., Schuman, G.E., 1997. Soil quality: a concept, definition, and framework for evaluation. Soil Science Society of America Journal 61(1): 4-10. 
Kazemi, K., Eskandari, H., 2011. Effects of salt stress on germination and early seedling growth of rice (Oryza sativa) cultivars in Iran. African Journal of Biotechnology 10(77): 17789-17792

Kizılkaya, R., 2005. The role of different organic wastes on zinc bioaccumulation by earthworm Lumbricus terrestris L. (Oligochaeta) in successive Zn added soil. Ecological Engineering 25(4): 322-331.

Kızılkaya, R., Așkın, T., Bayraklı, B., Sağlam, M., 2004. Microbiological characteristics of soils contaminated with heavy metals. European Journal of Soil Biology 40(2): 95-102.

Kızılkaya, R., Bayraklı, B., 2005. Effects of N-enriched sewage sludge on soil enzyme activities. Applied Soil Ecology 30(3): 192-202.

Kızılkaya, R., Hepşen, Ş., 2007. Microbiological properties in earthworm Lumbricus terrestris L. cast and surrounding soil amended with various organic wastes. Communication in Soil Science and Plant Analysis 38(19-20): 28612876.

Ladd, J.N., Butler, J.H.A., 1972. Short-term assays of soil proteolytic enzyme activities using proteins and dipeptide derivatives as substrates. Soil Biology and Biochemistry 4(1): 19-39.

Lax, A., Diaz, E., Castillo, V., Albaladejo, J., 1994. Reclamation of physical and chemical properties of a salinized soil by organic amendment. Arid Soil Research and Rehabilitation 8(1): 9-17.

Leirós, M.C., Trasar-Cepeda, C., Seoane, S., Gil-Sotres, F., 2000. Biochemical properties of acid soils under climax vegetation (Atlantic oakwood) in an area of the European temperate-humid zone (Galicia, NW Spain): general parameters. Soil Biology and Biochemistry 32(6): 733-745.

Mahdy, A.M., 2011. Comparative effects of different soil amendments on amelioration of saline-sodic soils. Soil and Water Research 6(4): 205-216.

Martin, J.P., 2003. Use of acid, rose Bengal, and streptomycin in the plate method for estimating soil fungi. Soil Science 69(3): 215-232.

Masciandaro, G., Ceccanti, B., Ronchi, V., Bauer, C., 2000. Kinetic parameters of dehydrogenase in the assessment of the response of soil to vermicompost and inorganic fertilisers. Biology and Fertility of Soils 32(6): 479-483.

Matsumoto, S., Zhao, Q., Yang, J., Zhu, S., Li, L., 1994. Salinisation and its environmental hazard on sustainable agriculture in East Asia and its neighbouring regions. 15th World Congress of Soil Science, Mexico, pp.236-255.

Nannipieri, P., Ascher, J., Ceccherini, M.T., Landi, L., Pietramellara, G., Renella, G., 2003. Microbial diversity and soil functions. European Journal of Soil Science 54(4): 655-670

Nannipieri, P., Ceccanti, B., Grego, S., 1990. Ecological significance of the soil biological activity in soil. In: Soil Biochemistry. Bollag, J.M., Stotzky, G. (Eds.). Marcel Dekker, New York, USA. pp. 415-471.

Oad, F.C., Samo, M.A., Soomro, A., Oad, D.L., Oad, N.L., Siyal, A.G., 2002. Amelioration of salt affected soils. Journal of Applied Sciences 2(1): 1-9.

Obbard, J.P., 2001. Measurement of dehydrogenase activity using 2-p-iodophenyl-3-p-nitrophenyl- 5-phenyltetrazolium chloride (INT) in the presence of copper. Biology and Fertility of Soils 33(4): 328-330.

Okur, N., Altındişli, A., Çengel, M., Göçmez, S., Kayıkçığlu, H.H., 2009. Microbial biomass and enzyme activity in vineyard soils under organic and conventional farming systems. Turkish Journal of Agriculture and Forestry 33: $413-423$.

Pepper, I.L., Gerba, C.P., Brendecke, J.W., 1995. Environmental microbiology: a laboratory manual. Academic Press, New York, USA. 197p.

Perucci, P., 1992. Enzyme activity and microbial biomass in a field soil amended with municipal refuse. Biology and Fertility of Soils 14(1): 54-60.

Qadir, M., Schubert, S., Ghafoor, A., Murtaza, G., 2001. Amelioration strategies for sodic soils: A review. Land Degradation and Development 12(4): 357-386.

Rossel, D., Tarradellas, J., 1991. Dehydrogenase activity of soil microflora: Significance in ecotoxicological tests. Environmental Toxicology 6(1): 17-33.

Rowell, D.L. 1996. Soil Science: Methods and Applications. Longman, London, UK. 368p.

Sumner, M.E., 1993. Sodic soils: New perspectives. Australian Journal of Soil Research 31(6): 683-750.

Tabatabai, M.A., 1994. Soil enzymes. In: Methods of soil analysis. Part 2- Microbiological and biochemical properties. Mickelson, S.H., Bighan, J.M. (Eds). (Eds.). ASA-SSSA, Madison, Wisconsin, USA. pp. 775-826.

Tabatabai, M.A., Bremner, J.M., 1969. Use of p-nitrophenyl phosphate for assay of soil phosphatase activity. Soil Biology and Biochemistry 1(4): 301-307.

Tabatabai, M.A., Bremner, J.M., 1970. Arylsulphatase activity of soils. Soil Science Society of America Journal 34(2): 225229.

Tiedje, J.M., Asuming-Brempong, S., Nüsslein, K., Marsh, T.L., Flynn, S.J., 1999. Opening the black box of soil microbial diversity. Applied Soil Ecology 13(2): 109-122.

Turner, B.L., Hopkins, D.W., Haygarth, P.M., Ostle, N., 2002. $\beta$-Glucosidase activity in pasture soils. Applied Soil Ecology 20(2): 157-162.

Umali, D., 1993. Irrigation-induced salinity. World Bank Tech. Paper No. 215, Washington, USA. 79p. Available at [access date : 16.06.2018]: http://documents.worldbank.org/curated/en/486611468766779740/pdf/multi-page.pdf

Yertayeva, Z., Kaldybaev, S., Beketova, A., 2018. The scientific basis of changes in the composition and properties of meadow saline soil of the foothill plains of the Ili Alatau during a long postmeliorative period. Ecology, Environment and Conservation 24(2): 715-720. 